\title{
Community Normal Reference Values for CD3+, CD4+, CD8+T Lymphocytes and Leucocytes among Immunocompetent Adults in Coastal Kenya
}

\author{
Shadrack A. Yonge ${ }^{1,2^{*}}$, Michael F. Otieno ${ }^{3}$, Rekha R. Sharma ${ }^{4}$, Sarah S. Nteka ${ }^{5}$ \\ ${ }^{1}$ Department of Environment and Health Sciences, Technical University of Mombasa, Mombasa, Kenya \\ ${ }^{2}$ Department of Community Health, Kenyatta University, Kahawa, Nairobi County, Kenya \\ ${ }^{3}$ Department of Medical Laboratory Sciences, Kenyatta University, Kahawa, Nairobi County, Kenya \\ ${ }^{4}$ Department of Zoological Sciences, Kenyatta University, Kahawa, Nairobi County, Kenya \\ ${ }^{5}$ Department of Medical Laboratory, Coast General Hospital, Mombasa, Kenya \\ Email: *shadrackyongez@yahoo.co.uk
}

How to cite this paper: Yonge, S.A., Otieno, M.F., Sharma, R.R. and Nteka, S.S. (2019) Community Normal Reference Values for CD3+, CD4+, CD8+T Lymphocytes and Leucocytes among Immunocompetent Adults in Coastal Kenya. Journal of Biosciences and Medicines, 7, 99-114. https://doi.org/10.4236/jbm.2019.71009

Received: August 30, 2018

Accepted: January 11, 2019

Published: January 14, 2019

Copyright $\odot 2019$ by authors and Scientific Research Publishing Inc. This work is licensed under the Creative Commons Attribution International License (CC BY 4.0).

http://creativecommons.org/licenses/by/4.0/

(c) $\underset{\mathrm{EY}}{\mathrm{C}}$ Open Access

\begin{abstract}
Background: Studies on the reference values of CD4 and CD3 T cells in healthy individuals have continued to gain significance because of the importance of these immunological markers in the initiation of antiretroviral therapy and prophylactic drugs for opportunistic infections. These ranges tend to vary across populations. The CD4:CD8 ratio is used to measure of how balanced immune function is. Therefore, this study aimed at determining normal reference values for $\mathrm{CD} 4+$ and $\mathrm{CD} 3+\mathrm{T}$-lymphocytes and leucocytes in healthy adults in Coastal Kenya. Methods: A cross-sectional study was carried between May 2015 and February 2016 in Coast General Referral hospital, Tudor, Port-Reitz, Mlaleo, Likoni and Sub-County hospitals. Participants were recruited from voluntary HIV counselling and testing clinics. Patients were counselled for HIV test and those who consented were tested for HIV. They were screened for diseases that potentially cause lymphocyte homeostasis perturbation. $\mathrm{CD} 4+, \mathrm{CD} 3+\mathrm{CD} 8+$ cells/ $\mu \mathrm{l}$ were analyzed using a $\mathrm{BD}$ FACSCount flow cytometer (Becton-Dickson, NJ). Results: We enrolled 500 participants, two hundred and forty (48.0\%) were males and two hundred and sixty (52.0) females. The mean CD4 cell count was $1054.9 \pm 95 \%$ CI 1041.2 - 1068.6 cells $/ \mathrm{mm}^{3}$, absolute CD8 was $688.4 \pm 95 \%$ CI $679.1-697.7$ cells $/ \mathrm{mm}^{3}$, absolute CD3 cell count was $1945.1 \pm 95 \%$ CI $1907.4-1982.2$ cells $/ \mathrm{mm}^{3}$ absolute leukocyte count $5.19 \pm 95 \%$ CI $5.12-5.19$, absolute lymphocyte count $1.85 \pm 95 \%$ CI1.83 - 1.88 and haemoglobin level $12.76 \pm 95 \%$
\end{abstract}


CI 12.65 - 12.87. Females had significantly higher mean CD4 and CD8 T cell counts than males $(\mathrm{p}<0.05)$. The mean values of white blood cells 4.7 (3.0 $7.9) \times 10^{9} / 1$, platelets $239(77-353) \times 10^{9} / 1$ and erythrocytes $4.65(3.51-5.40)$ $\times 10^{9}$ were significantly higher in males than females $(\mathrm{p}<0.05)$. Conclusion: Immunohaematological markers found in this study were different from the standard values for the western countries. Females had significantly higher mean $\mathrm{CD} 4+\mathrm{T}$ and $\mathrm{CD} 3+\mathrm{T}$ cell counts but lower mean haemoglobin level, erythrocytes, white blood cells and platelets than males. Our findings provide new insight in the CD4 and CD3 T cell reference values of Kenyans.

\section{Keywords}

CD3 \& CD4 Count, Range, T-Lymphocyte, Kenya

\section{Introduction}

Immunohaematological indices such as leukocyte, lymphocytes and their subsets such as CD3+T cells, CD4+T cells and CD8+T cells play a major role in both cellular and humoral types of immunity. $T$ lymphocyte cells are defined by the expression of CD3+ molecules. The most important cell-surface molecules for identifying $\mathrm{T}$ lymphocyte subpopulations have been $\mathrm{CD} 4+, \mathrm{CD} 8+$, and $\mathrm{T}$-cell receptor complex molecules (CD3+, the T-cell receptor $\alpha$ and $\beta$ chains) [1]. $\mathrm{CD} 4+\mathrm{T}$ cells are the lymphocytes subsets used for monitoring progression of HIV/AIDS infection and they are also used as a surrogate marker for the improvement of HIV/AIDS patients after initiation of ARV [2]. Lymphocyte subset may include; Helper T cells (CD4 T cells), Cytotoxic T cells (CTLs or CD8 T-cells), Memory T cells and Regulatory cells (Treg cells). Upon encounter with antigens, CD4 $\mathrm{T}$ cells become activated and proliferate rapidly secreting cytokines that send signals and maintain active immune response. On the other hand, CD8+T-cells destroy virally infected cells and tumor cells, and remain inactivated when there is no foreign antigen. In human immunodeficiency virus-1 (HIV-1) infected individuals, lymphocytes (specifically CD4 T-cells) are the viral prime targets. Therefore in these individuals, a CD4+T count provides a picture of immune system competence, with higher CD4 counts typically signifying healthier immune systems [3] [4]. Further, CD4+T cell level determines when to start or stop prophylactic drugs for opportunistic infections [5]. Less than 350 cells/ $\mu$ is considered a threshold for starting ART in HIV-positive patients without other indications in many high-income countries [6] [7] although not all [8] and some commentators argue that with newer, safer antiretrovirals, there should be commencement of therapy at a higher threshold of CD4+T count [9]. Similar levels of cut-off are encouraged for low-income countries where feasible [10] despite some evidence that treatment may be delayed further without increasing the risk of AIDS related events [11] [12].

Reference ranges that are currently used in Kenya are derived from data ob- 
tained from Caucasians who are not African Kenyans. In addition, these ranges do not include age and sex which are very important factors that influence lymphocyte counts [13]. Immunohaematological variations have been reported in various studies, showing association with sex [14] [15], geographical location, race, altitude and diet [16] [17] [18] [19]. Other reasons for variations are pregnancy, age [20] [21], exercise, cormobid conditions and diurnal variation [22] [23] [24], in addition to variations caused by methodological differences. Averagely, healthy African and Asian populations have been shown to have lower CD4 lymphocyte counts than counts than their western European and Caucasian counterparts [25]-[33]. The pattern of lymphocyte generation has been shown to effect the levels of circulating lymphocytes in males, females and individuals of different ages. The pattern of $\mathrm{T}$ lymphocyte generation in aging has been associated with dynamic changes in thymic and extrathymic functions along developmental steps from cells to mature cells [34]. Increased absolute numbers of peripheral blood CD4+T cells in females compared to males have been reported [35]. This is perhaps due to androgens which accelerate thymocytes apoptosis and subsequently influence $\mathrm{T}$ cell repertoire with males tending to have less $\mathrm{CD} 4+\mathrm{T}$ cells than females [36] [37]. This necessitates the importance of establishing local immunological reference values (CD3 and CD4+T cells for local Kenyan population). The study provides ranges specific for males and females of different age groups.

\section{Materials and Methods}

\subsection{Study Design, Setting and Population}

A cross-sectional study was conducted in Coastal region of Kenya which has a population of 1,031,266 between May 2015 and February 2016. The study was done at Coast provincial General hospital (CPGH), Mlaleo, Mikindani, Likoni, Portreizt and Tudor Sub County hospitals. These hospitals have HIV voluntary counselling and testing (VCT) services.

\subsection{Study Subjects}

Study population were adults who were attending HIV-Voluntary counselling and testing (VCT). The VCT services are offered in hospitals with Modern equipment's for immunohaematological testing. Eligible subjects were those aged 18 years, those who agreed to participate in the study, free from clinical disease conditions, looking apparently healthy, who lived in the area at least in the past six months having body mass index between $17.5 \mathrm{~kg} / \mathrm{m}^{2}$ and $22 \mathrm{~km}^{2}$ and HIV negative. Those who consented were asked for blood samples for repeat HIV test, and immunohaematological counts. Blood was collected in ethylene diamine-tetra-acetic acid (EDTA) tubes. The same samples were used for repeat HIV test, CBC, CD4 T-cell and CD8 T-cell counts. Samples were collected in the morning from 8.30 am to 10.30 am and kept at room temperature and transferred Coast General Referral hospital and Portreitz Sub county hospital for 
analysis the same day. This was done to control possible diurnal variations for $\mathrm{T}$ lymphocyte counts. A structured questionnaire was used to collect information on the history and general health status of the subjects. The samples were screened for HIV, Hepatitis B virus (HBV), Hepatitis C virus (HCV), malaria and syphilis after blood collection.

The following categories were excluded: pregnant mothers, patients receiving medical treatment, individuals with history of recent or current cormobid conditions, chronic alcoholism and moderate and severe malnourishment (BMI < $\left.17.5 \mathrm{~kg} / \mathrm{m}^{2)}\right)$, recent past immunization in the last 6 months, blood or blood product transfusion in the last six months, Patients with malaria and individuals who tested for HIV antibody.

\subsection{Laboratory Procedures}

\subsubsection{Screening for Malaria, Syphilis, HCV and HBV}

Enzyme linked immunoassays were used in screening for these conditions. Commercially available kits containing purified antigens were used. The kits included: ICE $^{\star}$ Syphilis, Murex anti-HCV (version 4.0), Hepanostika HBsAg Ultra kit, Murex HIV-1.2.0 (Abbot) and malaria antigen detection kit (Creative diagnostics).

\subsubsection{HIV Testing}

Blood samples were tested for HIV antibodies according to the Kenyan national testing algorithm for voluntary counseling and testing. Testing for HIV infection was done by screening serum/plasma by using Determine HIV1/2 (Abott laboratories, Japan co. LTD), Capillus HIV1/2 (The Trinity Biotech, Bray, Co Wicklow, Ireland) and Unigold H1/2 rapid test kits. Concordant positive results were interpreted as positive for HIV antibody. Discordant results were interpreted as inconclusive and the samples were confirmed using ELISA; Enzygnost and anti-HIV $1+2$ Plus ELISA (Behring, Marburg, Germany) and well-coenzyme HIV recombinant ELISA (Murex, Dartford, England).

\subsubsection{Haematological Assay}

Complete blood cell counts were done using Sysmex Kx-21 (Sysmex Corporation; Kobe Japan). The machine automatically dilutes a whole-blood sample, lyses, counts and gives a printout result of absolute numbers of leucocytes (expressed as number of cells $\times\left[10^{9}\right]$ per liter), erythrocytes (number of cells $\times$ $\left[10^{12}\right]$ per liter), platelets (number of cells $\times\left[10^{9}\right]$ per liter), lymphocytes (number of cells $\times\left[10^{9}\right]$ per liter), mononuclear cells (number of cells $\times\left[10^{9}\right]$ per liter), granulocytes (number of cells $\times\left[10^{9}\right]$ per liter) and haemoglobin (grams per decilitre). The quality and accuracy of the technique and the machine was assessed every six months.

\subsubsection{CD3, CD4+T and CD8+T Cell Determination}

Cluster of differentiation 3 and 4 (CD3 \& CD4 T) cells were enumerated using a FACSCount flow cytometer (Becton Dickinson Immunocytometry Systems, San Jose, Calif.). The BD FACScount ${ }^{\text {Tw }}$ System is designed to provide CD4 and CD3 T 
cell absolute values and percentage per microlitre of sample. The system includes BD FACScount instrument, software, reagents, controls and a workstation. In brief, $50 \mu \mathrm{l}$ of whole blood was mixed with monoclonal antibodies (MAbs) $(5 \mu \mathrm{L}$ of each $\mathrm{T}$ lymphocytes reagent tubes) and incubated at room temperature for 20 min with $20 \mu \mathrm{l}$ of aCD4 and aCD8. Red blood cells were then lysed by adding $450 \mu \mathrm{l}$ of fluorescence-activated cell sorter lysing solution (Becton Dickinson Immunocytometry Systems). The tubes were incubated at room temperature for 10 min, and then analyzed with the FACSCounts's Cell Quest software (Becton Dickinson Immunocytometry Systems) within six hours. By using quality control (Multicheck; Becton Dickinson Immunocytometry Systems), the accuracy of the technique was assessed every 6 months.

\section{Quality control}

The FACSCaliber was calibrated and reconfirmed daily using the BD Caliber the BD Calibrate beads and BD-FACS Comp soft-ware, version 2.0 for setting the photomultiplier tube voltages, setting the fluorescence compensation and checking instrument sensitivity before use. The CD45 versus the side scatter (SSC) dot plot was visually inspected to make sure they appear as a bright compact cluster, with low SSC.

\subsection{Screening for Malnutrition}

All participants were assessed for malnutrition using body mass index (BMI). Normal nutrition status was defined as BMI $>18.5 / \mathrm{kg} / \mathrm{m}^{2}$, mild malnutrition as BMI of $17.5-18.4 \mathrm{~kg} / \mathrm{m}^{2}$, moderate malnutrition as BMI of $16-17.4 \mathrm{~kg} / \mathrm{m}^{2}$ and severe malnutrition as $\mathrm{BMI}<16 \mathrm{~kg} / \mathrm{m}^{2}$. [38]

\subsection{Data Management and Analysis}

Completed questionnaires were coded and doubled entered in computer software Epi-data version 13.1. Cross-checking and data cleaning was done. The data was the transferred to SPSS version 20.0 for analysis. Non parametric reference range determination was employed by estimating the 2.5 and 7.5 percentile [39]. The significance of differences between the mean absolute counts and percentages of the Lymphocyte subsets were estimated using the Analysis of Variance (ANOVA) and T-test. Multiple comparisons were done using Tukey's test. Correlation analysis was applied in determining the relationship between lymphocyte subset levels and age.

\subsection{Ethical Issues}

The protocol was approved by Kenyatta University Ethical Review Committee. Clearance was also obtained from respective district health authorities and hospital administrations. The purpose of the study was explained participants in English, Kiswahili or local language before written consent was sought. The study was conducted in accordance with the declaration of Helsinki. Those participants, who had HIV infection, were referred to the HIV care and treatment 
clinic for further management after counseling. Female participants who were reactive for hcG test were referred to antenatal clinic for better care.

\section{Results}

\subsection{Baseline Characteristics of the Study Participants}

Among the 500 individuals between the ages 18 - 55 years, $48.0 \%$ (240) were males and $52.0 \%$ (260) were females. Their blood samples were analysed for CD3, CD4 and CD8 lymphocyte subset for establishment of reference ranges. Changes in age influenced the subset values marginally in both sexes. With the advancement of age, the CD4 mean counts decreased consistently both males and females though there was a slight increase in males age between $41-50$ years. However, the age dependent changes did not achieve the statistical significance. Women had comparatively higher CD4 mean counts than their male counterparts. The difference was statistically insignificant. On the other hand, males had higher CD8 mean counts compared to females (710.9 \pm 113.8 cells $/ \mathrm{mm}^{3}$ and $667.7 \pm 93.6$ cells $/ \mathrm{mm}^{3}$ ) respectively. The difference again was again statistically insignificant. However, significantly higher mean CD4/CD8 ratios were found in females as compared to males, $1.42 \pm 0.17$ cells $/ \mathrm{mm}^{3}$ and $1.69 \pm 0.49$ cells $/ \mathrm{mm}^{3}(\mathrm{p}<0.05)$. In both the sexes, the CD4 mean counts were always higher than the CD8 mean counts irrespective of age (Table 1).

\subsection{Immunohaematological Reference Values in Human Immunodeficiency Virus Negative Patients.}

The mean CD4+T count in males and females combined was $1054.9 \pm 156.1$ cells $/ \mathrm{mm}^{3}$, mean absolute CD4+T lymphocyte in males was $998.7 \pm 127.1$ cells $/ \mathrm{mm}^{3}$ and in females $1106.8 \pm 162.4$ cells $/ \mathrm{mm}^{3}$. The Mean absolute CD8+T cells in males and females combined was $688.4 \pm 105.9$ cells $/ \mathrm{mm}^{3}$ and mean absolute CD8+T counts in males were $710.9 \pm 113.8$ cells $/ \mathrm{mm}^{3}$ and in females $667.7 \pm 93.6$ cells $/ \mathrm{mm}^{3}$. The absolute combined was CD3+T in was $1945.1 \pm$ 429.2 cells $/ \mathrm{mm}^{3}$ and mean absolute CD3+T counts in males were $1871.3 \pm 355.2$ cells $/ \mathrm{mm}^{3}$ and in females $2013.2 \pm 478.3$ cells $/ \mathrm{mm}^{3}$. The mean CD4/CD8+T cells ratio in males and females combined was $1.56 \pm 0.39$, cells $/ \mathrm{mm}^{3}$. Mean $\mathrm{CD} 4 / \mathrm{CD} 8+\mathrm{T}$ cells in males were $1.42 \pm 0.17$ while in females $1.69 \pm 0.49$ cells $/ \mathrm{mm}^{3}$. Females had significantly higher mean absolute CD4+ cells $(\mathrm{t}=8.32$, df 485.2, $\mathrm{p}=0.001)$ and lower mean absolute CD8+T cells $(\mathrm{t}=4.62, \mathrm{df}=463.8, \mathrm{p}$ $<0.05)$ than in males. The haemoglobin level in males and females combined was $12.76 \pm 1.28 \mathrm{gram} / \mathrm{dl}$. Mean haemoglobin level in males was $13.06 \pm 1.48$ $\mathrm{gm} / \mathrm{dl}$ and in females $12.48 \pm 1.00 \mathrm{gm} / \mathrm{dl}$. Females had significantly lower mean haemoglobin level than males $(t=5.06, d f, 416, p=0.002)$ as shown in Table 2 .

\subsection{Males and Females with Lower than Normal Values of CD4 T Cells, Leukocytes, Lymphocytes and Body Mass Index}

The mean absolute leukocytes cells in both males and females was $5.15 \pm 0.37$ 
cells/litre. Mean absolute leukocytes cells in males was $4.89 \pm 0.22$ cells/litre and in females $5.40 \pm 0.30$ cells/litre. Mean absolute lymphocytes cells in males and females combined were $1.85 \pm 0.29$ cells/litre. The mean lymphocyte in males was $1.67 \pm 0.20$ cells/litre while in females mean was $2.02 \pm 0.26$ cells/litre. On nutritional status assessment using BMI, the mean BMI for the participants was $22.6 \pm 95 \%$ CI: $22.5-22.7 \mathrm{~kg} / \mathrm{m}^{2}$. Mean BMI for males was $22.4 \pm 95 \%$ CI: $22.3-$ $22.6 \mathrm{~kg} / \mathrm{m}^{2}$ and for females $22.9 \pm 95 \%$ CI: $22.8-23.1 \mathrm{~kg} / \mathrm{m}^{2}$. There was no

Table 1. Age distribution of immunocompetent adults in Coastal Kenya.

\begin{tabular}{|c|c|c|c|c|c|c|c|}
\hline \multirow[b]{2}{*}{ Age group } & \multicolumn{4}{|c|}{ Male } & \multicolumn{3}{|c|}{ Female } \\
\hline & Subsets & $\mathbf{n}$ & Mean \pm SD & $95 \% \mathrm{CI}$ of the Mean & $\mathrm{n}$ & Mean \pm SD & $95 \%$ C.I of the Mean \\
\hline \multirow{5}{*}{$18-20$} & & & $1159.5 \pm 124.8$ & $1105.5-1213.4$ & & $1271.0 \pm 155.8$ & $1206.7-1335.4$ \\
\hline & $\begin{array}{l}\mathrm{CD} 4 \\
\mathrm{CD} 8\end{array}$ & & $793.0 \pm 133.7$ & $735.1-850.8$ & & $767.2 \pm 106.1$ & $723.4-810.9$ \\
\hline & $\mathrm{CD} 3$ & 23 & $2006.5 \pm 281.7$ & $1884.7-2128.3$ & 25 & $2231.9 \pm 445.9$ & $2047.9-2416.0$ \\
\hline & $\begin{array}{c}\text { CD4/CD8 } \\
\mathrm{HB}\end{array}$ & & $1.49 \pm 0.21$ & $1.40-1.58$ & & $1.67 \pm 0.21$ & $1.58-1.76$ \\
\hline & & & $13.15 \pm 1.26$ & $12.61-13.70$ & & $12.29 \pm 0.85$ & $11.94-12.64$ \\
\hline \multirow{5}{*}{$21-30$} & & & $992.5 \pm 99.7$ & $977.0-1007.9$ & & $1120.0 \pm 136.9$ & $1098.1-1141.9$ \\
\hline & $\begin{array}{l}\mathrm{CD} 4 \\
\mathrm{CD} 8\end{array}$ & & $709.4 \pm 101.8$ & $693.6-725.2$ & & $664.1 \pm 90.0$ & $649.7-678.4$ \\
\hline & $\mathrm{CD} 3$ & 162 & $1852.2 \pm 347.8$ & $1798.2-1906.2$ & 153 & $2003.3 \pm 455.1$ & $1930.6-2076.0$ \\
\hline & $\begin{array}{c}\text { CD4/CD8 } \\
\mathrm{HB}\end{array}$ & & $1.43 \pm 0.14$ & $1.38-1.47$ & & $1.74 \pm 0.60$ & $1.64-1.83$ \\
\hline & & & $13.04 \pm 1.54$ & $12.80-13.28$ & & $12.52 \pm 1.05$ & $12.35-12.69$ \\
\hline \multirow{5}{*}{$31-40$} & & & $933.2 \pm 112.6$ & $899.4-967.1$ & & $1049.4 \pm 161.9$ & $1009.6-1089.2$ \\
\hline & $\begin{array}{l}\mathrm{CD} 4 \\
\mathrm{CD} 8\end{array}$ & & $657.9 \pm 76.2$ & $635.0-680.8$ & & $650.4 \pm 78.8$ & $631.0-669.7$ \\
\hline & $\mathrm{CD} 3$ & 45 & $1834.4 \pm 379.0$ & $1720.6-1948.3$ & 66 & $1960.0 \pm 536.3$ & $1829.2-2091.9$ \\
\hline & $\begin{array}{c}\text { CD4/CD8 } \\
\mathrm{HB}\end{array}$ & & $1.43 \pm 0.14$ & $1.38-1.47$ & & $1.62 \pm 0.23$ & $1.57-1.68$ \\
\hline & & & $13.05 \pm 1.34$ & $12.65-13.45$ & & $12.46 \pm 1.00$ & $12.21-12.70$ \\
\hline \multirow{5}{*}{$41-50$} & & & $1024.9 \pm 249.2$ & $846.6-1203.2$ & & $968.2 \pm 174.3$ & $871.7-1064.7$ \\
\hline & $\begin{array}{l}\mathrm{CD} 4 \\
\mathrm{CD} 8\end{array}$ & & $784.9 \pm 221.0$ & $626.8-943.0$ & & $618.9 \pm 64.4$ & $583.3-654.6$ \\
\hline & $\mathrm{CD} 3$ & 10 & $1852.2 \pm 347.8$ & $1798.8-1906.2$ & 15 & $2011.1 \pm 442.7$ & $1766.0-2256.3$ \\
\hline & $\begin{array}{c}\text { CD4/CD8 } \\
\mathrm{HB}\end{array}$ & & $1.36 \pm 0.34$ & $1.12-1.60$ & & $1.56 \pm 0.18$ & $1.46-1.66$ \\
\hline & & & $13.16 \pm 1.68$ & $11.96-14.40$ & & $12.53 \pm 0.79$ & $12.10-12.97$ \\
\hline \multirow{5}{*}{$50+$} & & & - & - & & 850 & - \\
\hline & $\begin{array}{l}\mathrm{CD} 4 \\
\mathrm{CD} 8\end{array}$ & & - & - & & 620 & - \\
\hline & $\mathrm{CD} 3$ & 0 & - & - & $1^{* *}$ & 1598 & - \\
\hline & $\begin{array}{c}\text { CD4/CD8 } \\
\text { HB }\end{array}$ & & - & - & & 1.37 & - \\
\hline & & & - & - & & 12.4 & \\
\hline \multirow{5}{*}{ Overall } & & & $998.7 \pm 127.1$ & $982.6-1014.9$ & & $1106.1 \pm 162.4$ & $1087.0-1126.6$ \\
\hline & $\begin{array}{l}\mathrm{CD} 4 \\
\mathrm{CD} 8\end{array}$ & & $710.9 \pm 113.8$ & $696.4-725.3$ & & $667.7 \pm 93.6$ & $656.3-679.1$ \\
\hline & $\mathrm{CD} 3$ & 240 & $1871.3 \pm 355.2$ & $1826.1-1916.4$ & 260 & $2013.2 \pm 478.3$ & $1954.8-2071.6$ \\
\hline & $\begin{array}{c}\text { CD4/CD8 } \\
\text { HB }\end{array}$ & & $1.42 \pm 0.17$ & $1.40-1.44$ & & $1.69 \pm 0.49$ & $1.63-1.75$ \\
\hline & & & $13.06 \pm 1.48$ & $12.87-13.25$ & & $12.48 \pm 1.00$ & $12.36-12.60$ \\
\hline
\end{tabular}

Unit of cells $/ \mu \mathrm{L}$ is not applicable to CD4/CD8 ratio; ${ }^{* *}$ Being only one case no value for mean \pm SD and $95 \%$ CI. 
Table 2. Arithmetic median, $2.5^{\text {th }}-97.5^{\text {th }}$ percentile, mean and $95 \%$ CI of the mean CD4+T cells, CD8+T cells, CD4/CD8 ratio and haemoglobin level in normal subjects (Controls).

\begin{tabular}{|c|c|c|c|c|c|c|c|}
\hline Sex & $\mathrm{N}$ & Median & $2.5^{\text {th }}-97.5^{\text {th }}$ percentile & Mean \pm SD & $95 \% \mathrm{CI}$ of the Mean & $\begin{array}{l}\text { Difference } \\
\text { in Means }\end{array}$ & $\begin{array}{c}\text { Difference } \\
\text { in Variance }\end{array}$ \\
\hline \multicolumn{8}{|c|}{ Absolute CD4 T cells } \\
\hline Males & 240 & 986 & $834.0-1319.9$ & $998.7 \pm 127.1$ & $982.6-1014.9$ & \multirow{3}{*}{$\begin{array}{c}\mathrm{t}=-8.32 \\
\mathrm{df}=485.2 \\
\mathrm{p}=0.001\end{array}$} & \multirow{3}{*}{$\mathrm{F}=19.94, \mathrm{p}<0.05$} \\
\hline Females & 260 & 1070 & $843.2-1503.9$ & $1106.8 \pm 162.4$ & $1087.0-1126.6$ & & \\
\hline Total & 500 & 1011.5 & $837.6-1464.8$ & $1054.9 \pm 156.1$ & $1041.2-1068.6$ & & \\
\hline \multicolumn{8}{|c|}{ Absolute CD8 T cells } \\
\hline Males & 240 & 690 & $540.1-1011.8$ & $710.9 \pm 113.8$ & $696.4-725.3$ & \multirow{3}{*}{$\begin{array}{c}\mathrm{t}=4.62 \\
\mathrm{df}=463.8 \\
\mathrm{p}=0.001^{*}\end{array}$} & \multirow{3}{*}{$\mathrm{F}=4.95, \mathrm{p}<0.05$} \\
\hline Females & 260 & 665 & $483.7-850.5$ & $667.7 \pm 93.6$ & $656.3-679.1$ & & \\
\hline Total & 500 & 673 & $497.5-973.8$ & $688.4 \pm 105.9$ & $679.1-697.7$ & & \\
\hline \multicolumn{8}{|c|}{ Absolute CD3 $\mathrm{T}$ cells } \\
\hline Males & 240 & 1815 & $1359.5-2929.4$ & $1871.3 \pm 355.2$ & $1826.1-1916.4$ & \multirow{3}{*}{$\begin{array}{l}\mathrm{t}=-3.79 \\
\mathrm{df}=476.5 \\
\mathrm{p}=0.004^{*}\end{array}$} & \multirow{3}{*}{$F=9.708, p<0.05$} \\
\hline Females & 260 & 1897.5 & $1433.0-3544.2$ & $2013.2 \pm 478.3$ & $1954.8-2071.6$ & & \\
\hline Total & 500 & 1860 & $1418.6-3073.8$ & $1945.1 \pm 429.2$ & $1907.4-1982.2$ & & \\
\hline \multicolumn{8}{|c|}{ CD4/CD8 T cells ratio } \\
\hline Males & 240 & 1.4 & $1.03-1.80$ & $1.42 \pm 0.17$ & $1.40-1.44$ & \multirow{3}{*}{$\begin{array}{l}\mathrm{t}=-8.48 \\
\mathrm{df}=325.8 \\
\mathrm{p}=0.001^{*}\end{array}$} & \multirow{3}{*}{$\mathrm{F}=8.85, \mathrm{p}<0.05$} \\
\hline Females & 260 & 1.61 & $1.35-2.23$ & $1.69 \pm 0.49$ & $1.63-1.75$ & & \\
\hline Total & 500 & 1.51 & $1.11-2.11$ & $1.56 \pm 0.39$ & $1.53-1.60$ & & \\
\hline \multicolumn{8}{|c|}{$\underline{\text { Hemoglobin level }}$} \\
\hline Males & 240 & 13 & $10.60-15.60$ & $13.06 \pm 1.48$ & $12.87-13.25$ & \multirow{3}{*}{$\begin{aligned} \mathrm{t} & =5.06 \\
\mathrm{df} & =416.5 \\
\mathrm{p} & =0.002^{\star}\end{aligned}$} & \multirow{3}{*}{$\mathrm{F}=19.94, \mathrm{p}<0.05$} \\
\hline Females & 260 & 12.5 & $10.20-14.50$ & $12.48 \pm 1.00$ & $12.36-12.60$ & & \\
\hline Total & 500 & 12.7 & $10.40-15.20$ & $12.76 \pm 1.28$ & $12.65-12.87$ & & \\
\hline
\end{tabular}

CD4+ = Cluster differentiation T-lymphocyte no.4, CD8+ = Cluster differentiation T-lymphocyte no.8; CD3+ = Cluster differentiation T-lymphocyte no.3; $\mathrm{SD}=$ standard deviation; $\mathrm{CI}=$ confidence interval; ${ }^{*}$ Statistically significant association.

significant statistical difference between males and females with regards to the nutritional status $\left(\chi^{2}=76.3, \mathrm{df}=1, \mathrm{p}>0.05\right)$. There was no significant association between nutritional status with any of the immunohaematological parameters like CD4+T cells and CD8+T cells and lymphocytes $(\mathrm{p}>0.05)$ but there was association between BMI and leukocytes $(p<0.05)$. Significant statistical differences was observed in the absolute count means of the lymphocytes in males and females $(\mathrm{p}<0.05)$. There was association between different age-groups and immunohaetological parameters like CD4+T cells $(\mathrm{p}<0.05)$ and CD8+T cells $(\mathrm{p}<$ 0.05) (Table 3).

\subsection{Haematological Reference Ranges in Immunocompetent Individuals}

Men had higher Haematocrit, erythrocyte counts, white blood cells counts, platelet counts and neutrophil percentage than women $(\mathrm{p}<0.05)$. Women had higher platelet and neutrophils counts (Table 4). 
Table 3. Males and females with lower than normal and normal values of CD4 T cells, leukocytes, lymphocytes and body mass index (Controls).

\begin{tabular}{|c|c|c|c|c|c|c|c|}
\hline Gender & $\mathbf{N}$ & Median & $\begin{array}{l}2.5^{\text {th }}-97.5^{\text {th }} \\
\text { percentile }\end{array}$ & Mean \pm SD & $\begin{array}{c}95 \% \text { CI of the } \\
\text { Mean }\end{array}$ & $\begin{array}{c}\text { Difference in } \\
\text { Means }\end{array}$ & $\begin{array}{l}\text { Difference in } \\
\text { Variances }\end{array}$ \\
\hline \multicolumn{8}{|c|}{ Absolute Leukocytes $\times 10^{9} / \mathrm{L}$} \\
\hline Males & 240 & 4.9 & $4.50-5.30$ & $4.89 \pm 0.22$ & $4.86-4.92$ & \multirow{3}{*}{$\begin{array}{l}\mathrm{t}=-21.98 \\
\mathrm{df}=471.2 \\
\mathrm{p}=0.003^{*}\end{array}$} & \multirow{3}{*}{$\mathrm{F}=18.97, \mathrm{p}<0.05$} \\
\hline Females & 260 & 5.4 & $4.70-5.90$ & $5.40 \pm 0.30$ & $5.36-5.43$ & & \\
\hline Total & 500 & 5.1 & $4.60-5.80$ & $5.19 \pm 0.37$ & $5.12-5.19$ & & \\
\hline \multicolumn{8}{|c|}{ Absolute Lymphocytes cells/litres } \\
\hline Males & 240 & 1.6 & $1.40-2.20$ & $1.67 \pm 0.20$ & $1.64-1.70$ & \multirow{3}{*}{$\begin{array}{l}t=-17.15 \\
d f=484.7 \\
p=0.001^{\star}\end{array}$} & \multirow{3}{*}{$\mathrm{F}=19.66, \mathrm{p}<0.05$} \\
\hline Females & 260 & 2 & $1.60-2.50$ & $2.02 \pm 0.26$ & $1.99-2.06$ & & \\
\hline Total & 500 & 1.8 & $1.40-2.50$ & $1.85 \pm 0.29$ & $1.83-1.88$ & & \\
\hline \multicolumn{8}{|c|}{ Nutritional status given as $\mathrm{BMI}$ in $\mathrm{kg} / \mathrm{m}^{2}$} \\
\hline Males & 240 & 22.75 & $19.20-24.49$ & $22.44 \pm 1.35$ & $22.27-22.61$ & \multirow{3}{*}{$\begin{array}{l}\mathrm{t}=-4.26 \\
\mathrm{df}=465.3 \\
\mathrm{p}=0.001^{\star}\end{array}$} & \multirow{3}{*}{$\mathrm{F}=7.32, \mathrm{p}<0.05$} \\
\hline Females & 260 & 23.1 & $19.80-24.60$ & $22.91 \pm 1.12$ & $22.77-23.05$ & & \\
\hline Total & 500 & 23 & $19.45-24.55$ & $22.68 \pm 1.25$ & $22.57-22.79$ & & \\
\hline
\end{tabular}

$\mathrm{BMI}=$ Body mass index; $\mathrm{SD}=$ standard deviation; $\mathrm{CI}=$ confidence interval; ${ }^{\star}$ Statistically significant association.

Table 4. Haematological reference ranges (median percentile) derived from immunocompetent individuals from Coastal Kenya.

\begin{tabular}{|c|c|c|c|}
\hline Parameters & All participants $(\mathrm{N}=500)$ & Male (240) & Female $(N=260)$ \\
\hline Haematocrit (\%) & $41.5(33.2-46.1)$ & $43.3(32.4-48.2)$ & $39.5(33.6-45.4)$ \\
\hline Erythrocytes $(10 / \mathrm{L})^{\mathrm{a}}$ & $4.65(3.51-5.40)$ & $4.8(3.8-5.6)$ & $4.5(3.5-5.6)$ \\
\hline Platelets $\left(10^{9} / \mathrm{L}\right)$ & $239(77-353)$ & $236(64-340)$ & $247(96-361)$ \\
\hline WBC $(\times 1000)$ & $4.7(3.0-7.9)$ & $4.8(3.3-7.5)$ & $4.7(3.1-7.4)$ \\
\hline $\mathrm{MCH}(\mathrm{pg})$ & $30.0(26.0-33.6)$ & $30.0(23.6-35.1)$ & $29.5(25.0-32.5)$ \\
\hline $\mathrm{MCV}(\mathrm{fL})$ & $86(73-96)$ & $87(70$ - 99) & $85(73-94)$ \\
\hline $\mathrm{MCHC}(\mathrm{g} / \mathrm{L})$ & $35.1(33.0-35.6)$ & $35.0(33.0-35.4)$ & $35.4(33.1-35.2)$ \\
\hline Neutrophils (no 109/L) & $2.20(1.05-3.65)$ & $2.19(1.05-4.39)$ & $2.19(1.05-3.70)$ \\
\hline Neutrophils (\%) & $46.0(26.1-61.3)$ & $45.5(24.0-60.4)$ & $46.5(26.1-56.5)$ \\
\hline Lymphocytes (no $10^{9} / \mathrm{L}$ ) & $1.85(1.83-1.88)$ & $1.67(1.64-1.70)$ & $2.01(1.99-2.06)$ \\
\hline Lymphocytes (\%) & $46.4(29.5-58.8)$ & $45.7(28.9-61.5)$ & $46.9(29.4-61.4)$ \\
\hline Monocytes (no $10^{9} / \mathrm{L}$ ) & $0.21(0.16-0.56)$ & $0.23(0.17-0.58)$ & $0.20(0.16-0.54)$ \\
\hline Monocytes (\%) & $6.6(4.4-10.5)$ & $6.9(4.6-12.4)$ & $6.3(4.0-10.7)$ \\
\hline Eosinophils (no $10^{9} / \mathrm{L}$ ) & $0.2(0.50-0.81)$ & $0.2(0.04-0.82)$ & $0.2(0.05-0.75)$ \\
\hline Eosinophils (\%) & $3.4(1-15.3)$ & $3.6(1.0-15.9)$ & $3.2(1.1-14.5)$ \\
\hline Basophils (no $10^{9} / \mathrm{L}$ ) & $0.05(0.03-0.09)$ & $0.05(0.03-0.09)$ & $0.05(0.03-0.09)$ \\
\hline Basophils (\%) & 1.0 & 1.0 & 1.0 \\
\hline
\end{tabular}




\section{Discussion}

In this study, the mean immunohematological reference values in healthy subjects for CD4+T and CD8+T counts was $1054.9 \pm 156.1 \mathrm{cells} / \mathrm{mm}^{3}$ and $998.7 \pm$ $127.1 \mathrm{cells} / \mathrm{mm}^{3}$ respectively. Our values were also higher than a number of reports in some countries. For instance, mean CD4 T cell values of 870.7 and 865 cells/ $\mu$ l have been reported among HIV seronegative individuals in Senegal and India, respectively [40] [41]. However, the mean CD4 T cells of 1067 cells/ $\mu 1$ reported in eastern Ghana by Ampofo et al. [42] is higher than our findings. This may not necessarily mean that Ghanaians have higher counts than Kenyans because the sample size for their study was just two hundred and fourty nine (249).

The study also found that females had significantly higher counts of absolute $\mathrm{CD} 4+\mathrm{T}$ cells and absolute CD8+T cells than males. This findings concur with earlier study done in Tanzania to determine gender difference in CD4 T cells, which showed that males were more likely to have CD4 T cells $<500$ cells $/ \mathrm{mm}^{3}$ [33]. This was probably due to biological factors. It has been speculated that gender and age-related variations within the immune system parameters may contribute to the pathogenesis of several gender and age-related diseases such as autoimmune disorders in female patients [43] [44] [45]. Diurnal variation, however, cannot explain the significant gender difference observed in this study, as all the samples were collected between $9.00 \mathrm{am}$ to $11.00 \mathrm{am}$. While smoking was also reported to be associated with higher $\mathrm{CD} 4+\mathrm{T}$ count, this could not be the reason for the difference as all female subjects in the present study were nonsmokers. Sex hormone effect could be the possible explanation for the observed gender difference in $\mathrm{CD} 4+\mathrm{T}$ cell count, as the circulating lymphocytes have receptors for androgens and oestrogens [46]. These variations in CD4+T cells have been shown to be associated with ethnicity, gender, diet, geographical area as well as being dependent on genetic and environmental factors. Further, it has been shown that there are gender differences in the generation of CD8 cells during HIV-1 infection, due to increased immune activation compared to men [47]. Females had significantly lower haemoglobin levels than males in our study. This is similar to findings in North America, Europe and Asia. Overall we found low haemoglobin levels compared to European values and the standard reference haemoglobin values. This can be partly explained by low dietary intake of food rich in iron and vitamins, which is the commonest causes of low haemoglobin levels in Kenya.

The absolute $\mathrm{T}$ lymphocytes mean, median, and the $95 \%$ normal reference interval value for the current study were also greater than the studies conducted from Switzerland by Bisset et al. [48], Shanghai, Chin [49] and Asian population [50]. These differences could be on our apparently healthy study population where they used only blood donors especially in Asian population and Switzerland studies. In our study we used large sample size compared to the other studies. CD3 and CD4 T cells did not correlate directly with age. This agrees with previous studies in China and India that found no significant association of CD4 
T cell values with age, but disagrees with a similar study in Nigeria among children [51] [48]. In this study the lymphocyte subsets in the different age groups revealed no significant differences. It is however well known that the pattern of $\mathrm{T}$ lymphocyte generation with age originates from dynamic changes in thymic as well as extrathymic functions, along with sequential developmental steps from stem cell to ultimately mature cells [52]. The finding of significant gender differences for the RBC parameters (erythrocytes, hemoglobin, and hematocrit) agrees with the well-established fact that males have higher values for erythrocytes, hemoglobin, and hematocrit than females, partly due to the influence of the hormone androgen on erythropoiesis and also due to menstrual loss. Significant differences between the genders with regard to WBC and platelet counts were observed in this study $(p<0.05)$. The general absence of gender differences for WBC counts disagrees with other reports [53] [54]. A study done Saudi Arabia showed a higher percentage and number of CD8+T cells $(\mathrm{p}<0.01)$ and a decreased CD4/CD8 ratio $(\mathrm{p}<0.02)$ compared with the Caucasian controls. Male population had a significantly lower percentage and number of activated T cells $(\mathrm{p}<0.05)[55]$.

\section{Conclusion}

Immunohaematological markers found in this study were different from the standard values for the western countries. The ranges are also different from those that are being used currently. Females had significantly higher mean $\mathrm{CD} 4+\mathrm{T}$ and $\mathrm{CD} 8+\mathrm{T}$ cell counts but lower mean haemoglobin level, erythrocytes, white blood cells and platelets than males. Our findings offer useful insight in the CD3 and CD4 T cell reference values of Kenyans and provide important information that will guide future ART decisions and other immune-based therapies.

\section{Acknowledgements}

The authors wish to thank individuals who participated in the study, the Medical Officer of Health, Medical Superintendents, Laboratory staff and clinical officers and nursing staff at Coast Provincial General Hospital, Portreitz, Tudor, Likoni, Mlaleo and Mikandani Sub-County hospitals who greatly assisted us with specimen and data collection for this study.

\section{Conflicts of Interest}

Authors have declared that no competing interests exist.

\section{Authors' Contribution}

This work was carried out in collaboration between all others. SAY and SSN conducted the study. MFO and RRS supervised the work SAY initiated the study and made major contributions to the study design. All authors helped to conceptualize ideas and interpret the results. SAY prepared the draft with other au- 
thors helped in review.

\section{References}

[1] Autran, B., Carcelain, G., Li, T.S., Blanc, C., Mathez, D., Tubiana, R., Katlama, C., Debre, P. and Leibowitch, J. (1997) Positive Effects of Combined Antiretroviral Therapy on CD4+T Cell Homeostasis and Function in Advanced HIV Disease. Science, 277, 112-116. https://doi.org/10.1126/science.277.5322.112

[2] Libamba, E., Makombe, S., Harries, A.D., Chimzizi, R., Salaniponi, F.M., Schouten, E.J. and Mpazanje, R. (2005) Scaling Up Antiretroviral Therapy in Africa: Learning from Tuberculosis Control Programmes-The Case of Malawi. International Journal of Tuberculosis and Lung Disease, 9, 1062-1071.

[3] Ahmadi, K., Hall, M., Norman, P., Vaughan, R., Snieder, H., Spector, T. and Lanchbury, J. (2001) Genetic Determinism in the Relationship between Human CD4 and CD8 Lymphocyte Populations. Genes and Immunity, 2, 381-387.

https://doi.org/10.1038/sj.gene.6363796

[4] Ampofo, W., Torpey, K., Mukadi, Y., Nolan, K., Amenyah, R., Kaito, E., Antwi, P., Ofori-Adjei, D. and Lamptey, P. (2006) Normal CD4 T Lymphocyte Levels in HIV Seronegative Individuals in the Manya/Yilo Krobo Communities in the Eastern Region of Ghana. Viral Immunology, 19, 260-266.

https://doi.org/10.1089/vim.2006.19.260

[5] Masur, H., Kaplan, J.E. and Holmes, K.K. (2002) Guidelines for Preventing Opportunistic Infections among HIV-Infected Persons-2002. Recommendations of the U.S. Public Health Service and the Infectious Diseases Society of America. Annals of Internal Medicine, 137, 435-478. https://doi.org/10.7326/0003-4819-137-5_Part_2-200209031-00002

[6] Department of Health and Human Services (2008) Panel on Antiretroviral Guidelines for Adults and Adolescents. Guidelines for the Use of Antiretroviral Agents in HIV-1-Infected Adults and Adolescents. 1-128.

[7] British HIV Association (2008) Guidelines for Treatment of HIV-Infected Adults with Antiretroviral Therapy. http://www.bhiva.org/files/file1030835.pdf

[8] Josephson, F., Albert, J., Flamholc, L., et al. (2007) Antiretroviral Treatment of HIV Infection: Swedish Recommendations 2007. Scandinavian Journal of Infectious Diseases, 39, 486-507. https://doi.org/10.1080/00365540701383154

[9] Gallant, J.E. (2007) Should Antiretroviral Therapy Be Started Earlier? Current HIV/AIDS Reports, 4, 53-59. https://doi.org/10.1007/s11904-007-0008-7

[10] Antiretroviral Therapy for HIV Infection in Adults and Adolescents: Recommendations for a Public Health Approach (2006). http://www.who.int/hiv/pub/guidelines/artadultguidelines.pdf

[11] Wood, E., Hogg, R.S., Yip, B., Harrigan, P.R., O’Shaughnessy, M.V. and Montaner, J.S. (2003) Is There a Baseline CD4 Cell Count That Precludes a Survival Response to Modern Antiretroviral Therapy? AIDS, 17, 711-120. https://doi.org/10.1097/00002030-200303280-00009

[12] Ahdieh-Grant, L., Yamashita, T.E., Phair, J.P., et al. (2003) When to Initiate Highly Active Antiretroviral Therapy: A Cohort Approach. American Journal of Epidemiology, 157, 738-746. https://doi.org/10.1093/aje/kwg036

[13] Ullrich, K., Koenigsmann, M., Mohren, M. and Franke, A. (2005) Lymphocyte Subsets Reference Ranges in an Age- and Gender-Balanced Population of 100 Healthy Adults-A Monocentric German Study. Clinical Immunology, 116, 192-197. 
https://doi.org/10.1016/j.clim.2005.03.020

[14] Maini, M.K., Gilson, R.J., Chavda, N., Gill, S., Fakoya, A., Ross, E.J. and Phillips, A.N. (1996) Weller: Reference Ranges and Sources of Variability of CD4 Counts in HIV-Seronegative Women and Men. Genitourinary Medicine, 72, 27-31.

[15] Prins, M., Robertson, J.R., Brettle, R.P., Aguado, I.H., Broers, B., Boufassa, F., Goldberg, D.J., Zangerle, R., Coutinho, R.A. and Hoek van den, A. (1999) Do Gender Differences in CD4 Cell Counts Matter?. AIDS, 13, 2361-2364.

[16] Nduka, N., Aneke, C. and Maxwell-Owhochuku, S. (1988) Comparison of Some Haematological Indices of Africans and Caucasians Resident in the Same Nigerian Environment. Haematologia (Budap), 21, 57-63.

[17] Miyawaki, T., Taga, K., Nagaoki, T., Seki, H., Suzuki, Y. and Taniguchi, N. (1984) Circadian Changes of T Lymphocyte Subsets in Human Peripheral Blood. Clinical \& Experimental Immunology, 55, 618-622.

[18] Espersen, G.T., Elbaek, A., Ernst, E., Toft, E., Kaalund, S., Jersild, C. and Grunnet, N. (1990) Effect of Physical Exercise on Cytokines and Lymphocyte Subpopulations in Human Peripheral Blood. APMIS, 98, 395-400. https://doi.org/10.1111/j.1699-0463.1990.tb01049.x

[19] Tsegaye, A., Messele, T., Tilahun, T., Hailu, E., Sahlu, T., Doorly, R., Fontanet, A.L. and Rinke de Wit, T.F. (1999) Immunohematological Reference Ranges for Adult Ethiopians. Clinical and Diagnostic Laboratory Immunology, 6, 410-414.

[20] Hulstaert, F., Hannet, I., Deneys, V., Munhyeshuli, V., Reichert, T., De Bruyere, M. and Strauss, K. (1994) Age-Related Changes in Human Blood Lymphocyte Subpopulations. II. Varying Kinetics of Percentage and Absolute Count Measurements. Clinical Immunology and Immunopathology, 70, 152-158. https://doi.org/10.1006/clin.1994.1023

[21] Tollerud, D.J., Clark, J.W., Brown, L.M., Neuland, C.Y., Pankiw-Trost, L.K., Blattner, W.A. and Hoover, R.N. (1989) The Influence of Age, Race, and Gender on Peripheral Blood Mononuclear-Cell Subsets in Healthy Nonsmokers. Journal of Clinical Immunology, 9, 214-222. https://doi.org/10.1007/BF00916817

[22] Jones, A.R., Twedt, D., Swaim, W. and Gottfried, E. (1996) Diurnal Change of Blood Count Analytes in Normal Subjects. American Journal of Clinical Pathology, 106, 723-727. https://doi.org/10.1093/ajcp/106.6.723

[23] Mientjes, G.H., van Ameijden, E.J., Roos, M.T., de Leeuw, N.A., Hoek van den, J.A., Coutinho, R.A. and Miedema, F.F. (1992) Large Diurnal Variation in CD4 Cell Count and T-Cell Function among Drug Users: Implications for Clinical Practice and Epidemiological Studies. AIDS, 6, 1269-1272. https://doi.org/10.1097/00002030-199211000-00005

[24] Malone, J.L., Simms, T.E., Gray, G.C., Wagner, K.F., Burge, J.R. and Burke, D.S. (1990) Sources of Variability in Repeated T-Helper Lymphocyte Counts from Human Immunodeficiency Virus Type 1-Infected Patients: Total Lymphocyte Count Fluctuations and Diurnal Cycle Are Important. Journal of Acquired Immune Deficiency Syndromes, 3, 144-151.

[25] Anglaret, X., Diagbouga, S., Mortier, E., Meda, N., Verge-Valette, V., Sylla-Koko, F., Cousens, S., Laruche, G., Ledru, E., Bonard, D., Dabis, F. and Perre Van de, P. (1997) CD4+ T-Lymphocyte Counts in HIV Infection: Are European Standards Applicable to African Patients? Journal of Acquired Immune Deficiency Syndromes and Human Retrovirology, 14, 361-367.

https://doi.org/10.1097/00042560-199704010-00009

[26] Feki, S., Rekaya, Z., Ben Chaaben, T., Zribi, A., Boukef, K. and Jenhani, F. (1998) 
Determination of T-lymphocyte Subsets in a North African Population (Tunisia): Establishment of Normal Ranges and Results in HIV-Infected Individuals. Disease Markers, 14, 161-164. https://doi.org/10.1155/1998/153450

[27] Levin, A., Brubaker, G., Shao, J.S., Kumby, D., O’Brien, T.R., Goedert, J.J., Strauss, K.W., Blattner, W.A. and Hannet, I. (1996) Determination of T-Lymphocyte Subsets on Site in Rural Tanzania: Results in HIV-1 Infected and Non-Infected Individuals. International Journal of STD \& AIDS, 7, 288-291. https://doi.org/10.1258/0956462961917825

[28] Menard, D., Mandeng, M.J., Tothy, M.B., Kelembho, E.K., Gresenguet, G. and Talarmin, A. (2003) Immunohematological Reference Ranges for Adults from the Central African Republic. Clinical and Diagnostic Laboratory Immunology, 10, 443-445.

[29] Messele, T., Abdulkadir, M., Fontanet, A.L., Petros, B., Hamann, D., Koot, M., Roos, M.T., Schellekens, P.T., Miedema, F. and Rinke de Wit, T.F. (1999) Reduced Naive and Increased Activated CD4 and CD8 Cells in Healthy Adult Ethiopians Compared with Their Dutch Counterparts. Clinical \& Experimental Immunology, 115, 443-450. https://doi.org/10.1046/j.1365-2249.1999.00815.x

[30] Tugume, S.B., Piwowar, E.M., Lutalo, T., Mugyenyi, P.N., Grant, R.M., Mangeni, F.W., Pattishall, K. and Katongole-Mbidde, E. (1995) Hematological Reference Ranges among Healthy Ugandans. Clinical and Diagnostic Laboratory Immunology, 2, 233-235.

[31] Uppal, S.S., Verma, S. and Dhot, P.S. (2003) Normal Values of CD4 and CD8 Lymphocyte Subsets in Healthy Indian Adults and the Effects of Sex, Age, Ethnicity, and Smoking. Cytometry Part B: Clinical Cytometry, 52, 32-36. https://doi.org/10.1002/cyto.b.10011

[32] Vithayasai, V., Sirisanthana, T., Sakonwasun, C. and Suvanpiyasiri, C. (1997) Flow Cytometric Analysis of T-Lymphocytes Subsets in Adult Thais. Asian Pacific Journal of Allergy and Immunology, 15, 141-146.

[33] Urassa, W.K., Lyamuya, E.F., Mbena, E., Kagoma, C., Bredberg Raden, U., Pallangyo, K.P., Magessa, P., Mhalu, F.S. and Biberfeld, G. (1996) Immunohaematological Findings in Healthy and HIV-1 Infected Adults in Dar es Salaam, Tanzania. East African Medical Journal, 73, 670-674.

[34] Lahita, R. (2000) Sex Hormones and Systemic Lupus Erythematosus. Rheumatic Disease Clinics of North America, 26, 951-968.

https://doi.org/10.1016/S0889-857X(05)70178-2

[35] Vajpayee, M., Kaushik, S., Sreenivas, V., Wig, N. and Seth, P. (2005) CDC Staging Based on Absolute CD4 Count and CD4 Percentage in an HIV-1-Infected Indian Poipulation: Treatment Implications. Clinical and Experimental Immunology, 141, 485-490. https://doi.org/10.1111/j.1365-2249.2005.02857.x

[36] Kalayjian, R., Landay, A., Pollard, R., Taub, D., Gross, B., Francis, I., Sevin, A., Pu, M., Spritzler, J., Chernoff, M., Namkung, A., Fox, L., Waterman, K., Fiscus, S., Sha, B., Johnson, D., Slater, S., Rousseau, F. and Lederman, M. (2003) Age Related Immune Dysfunction in Health and in Human Immunodeficiency Virus (HIV) Disease: Association of Age and HIV Infection with Naive CD8 Cell Depletion, Reduced Expression of CD28 on CD8 Cells and Reduced Thymic Volumes. The Journal of Infectious Diseases, 187, 1924-1933. https://doi.org/10.1086/375372

[37] Olsen, N. and Kovacs, W. (2001) Effects of Androgens on T and B Lymphocyte Development. Immunologic Research, 23, 281-288.

https://doi.org/10.1385/IR:23:2-3:281 
[38] Ferro-Luzzi, A., Franklin, M. and James, W.P. (1992) A Simplified Approach of Assessing Adult Chronic Energy Deficiency. European Journal of Clinical Nutrition, 46, 73-186.

[39] NCCLS (2000) How to Define and Determine Reference Intervals in the Clinical Laboratory; Approved Guideline. 2nd Edition, National Committee for Clinical Laboratory Standards, Wayne, PA, C28-A2, Vol. 20, p. 13.

[40] Forbi, J.C. and Agwale, S.M. (2009) Inverted CD4 ${ }^{+} / \mathrm{CD}^{+}$Ratio Associated with AIDS Event and Death in HIV-1 infected individuals in Nasarawa State, Nigeria. Tanzania Journal of Health Research, 11, 144-148.

[41] Uppal, S.S., Verma, S. and Dhot, P.S. (2003) Normal Values of CD4 and CD8 Lymphocyte Subsets in Healthy Indian Adults and the Effects of Sex, Age, Ethnicity and Smoking. Cytometry, 52, 32-36. https://doi.org/10.1002/cyto.b.10011

[42] Lugada, E.S., Mermin, J. and Kaharuza, F. (2004) Population-Based Hematologic and Immunologic Reference Values for a Healthy Ugandan Population. Clinical and Diagnostic Laboratory Immunology, 11, 29-34.

[43] Mair, C., Hawes, S., Agne, H., Sow, P., N'dove, I., Manhart, L., Fu, P., Gottlieb, G. and Kiviat, N. (2007) Factors Associated with CD4 Lymphocyte Counts in HIV-Negative Senegalese Individuals. Clinical \& Experimental Immunology, 151, 432-440. https://doi.org/10.1111/j.1365-2249.2007.03573.x

[44] Ngowi, B., Mfinanga, S., Bruun, J. and Morkve, O. (2009) Immunohaematological Reference Values in Human Immunodeficiency Virus-Negative Adolescent and Adults in Rural Northern Tanzania. BMC Infectious Diseases, 9, 1-7. https://doi.org/10.1186/1471-2334-9-1

[45] Santagostino, A., Garbaccio, G., Pistorio, A., Bolis, V., Camisasca, G., Pagliaro, P. and Girotto, M. (1999) An Italian National Multicenter Study for the Definition of Reference Ranges for Normal Values of Peripheral Blood Lymphocyte Subsets in Healthy Adults. Haematologica, 84, 499-504.

[46] Schaberge, T., Theilacker, C., Nitschke, O. and Lode, H. (1997) Lymphocyte Subsets in Peripheral Blood and Smoking Habits. Lung, 175, 387-394. https://doi.org/10.1007/PL00007585

[47] Meier, A., Chang, J., Chan, E., Pollard, R., Sidhu, H., Kulkarni, S., Wen, T., Lindsay, R., Orellana, L., Mildvan, D., Bazner, S., Streeck, H., Alter, G., Lifson, J., Carrington, M., Bosch, R., Robbins, G. and Altfeld, M. (2009) Sex Differences in the Toll-Like Receptor-Mediated Response of Plasmocytoid Dendritic Cells to HIV-1. Nature Medicine, 15, 955-959. https://doi.org/10.1038/nm.2004

[48] Bisset, L.R., Lung, T.L., Kaelin, M., Ludwig, E. and Dubs, R.W. (2004) Reference Values for Peripheral Blood Lymphocyte Phenotypes Applicable to the Healthy Adult Population in Switzerland. European Journal of Haematology, 72, 203-212. https://doi.org/10.1046/j.0902-4441.2003.00199.x

[49] Jiang, W., Kang, L., Lu, H., et al. (2004) Normal Values for CD4 and CD8 Lymphocyte Subsets in Healthy Chinese Adults from Shanghai. Clinical and Diagnostic Laboratory Immunology, 11, 811-813.

[50] Chng, W., Tan, G. and Kuperan, P. (2004) Establishment of Adult Peripheral Blood Lymphocyte Subset Reference Range for an Asian Population by Single-Platform Flow Cytometry: Influence of Age, Sex, and Eace and Comparison with Other Published Studies. Clinical and Diagnostic Laboratory Immunology, 11, 168-173.

[51] Idigbe, E.O., Audu, R.A., Iroha, E.O., et al. (2010) T-Lymphocyte Subsets in Apparently Healthy Nigerian Children. International Journal of Pediatrics, 2010, Article ID: 474380. https://doi.org/10.1155/2010/474380 
[52] Globerson, A. (1997) Thymocytopoiesis in Aging: The Bone Marrow-Thymus Axis. Archives of Gerontology and Geriatrics, 24, 141-155. https://doi.org/10.1016/S0167-4943(96)00747-9

[53] Badenhorst, C.J., Fourie, J., Steyn, K., Jooste, P.L., Lombard, C.J., Bourne, L. and Slazus, W. (1995) The Haematological Profile of Urban Black Africans Aged 15 - 64 Years in the Cape Peninsula. East African Medical Journal, 72, 19-24.

[54] Messele, T., Abdulkadir, M., Fontanet, A.L., Petros, B., Hamann, D., Koot, M., Roos, M.T., Schellekens, P.T., Miedema, F. and Rinke de Wit, T.F. (1999) Reduced Naive and Increased Activated CD4 and CD8 Cells in Healthy Adult Ethiopians Compared with Their Dutch Counterparts. Clinical \& Experimental Immunology, 115, 443-450. https://doi.org/10.1046/j.1365-2249.1999.00815.x

[55] Shahabuddin, S. (1995) Quantitative Differences in CD8 + Lymphocytes, CD4/CD8 ratio, NK-Cells, and HLA-DR ${ }^{+}$-Activated T Cells of Racially Different Male Populations. Clinical Immunology and Immunopathology, 75, 168-170.

https://doi.org/10.1006/clin.1995.1067

\section{List of Abbreviations}

HIV: Human immunodeficiency virus; SSC: Side scatter; ANOVA: Analysis of variance; CD4: cluster of differentiation 4; CD8: cluster of differentiation 8 